\title{
KAJIAN KRITIS PERILAKU HUMANITAS PENDIDIK TERHADAP PESERTA DIDIK DALAM PROSES PENDIDIKAN DI KOTA MALANG
}

\author{
Mohammad Zaini'), Wilyati Agustina ${ }^{2)}$ \\ Institut Keguruan Ilmu Pendidikan (IKIP) Budi Utomo Malang \\ Email : ${ }^{1}$ pojur_zen@yahoo.com \\ Email : ${ }^{2}$ wilyanti_b@yahoo.com
}

\begin{abstract}
ABSTRAK
Penelitian ini dilakukan untuk menganalisis pola hubungan kemanusiaan pendidik dan peserta didik dalam proses pendidikan, sehingga terbukti secara empirik tentang perilaku humanitas pendidik terhadap peserta didik dalam proses pendidikan di kota Malang. Selanjutnya peneliti memberikan tawaran konsep peningkatan kualitas humanitas pendidik dalam proses pendidikan di kota Malang. Pendekatan dilakukan menggunakan penelitian kualitatif-fenomenologis. Instrumen penelitian yang digunakan; indepth interview, dokumentasi, dan observasi. Model analisis yang digunakan adalah: Miles Huberman. Grand theory; teori humanisasi Freire. Berdasarkan hasil analisis peneliti, dijabarkan bahwa: perilaku humanitas pendidik terhadap peserta didik dalam proses pendidikan di (SDN X dan SDN Y) kota Malang masih menemui kendala paradigmatis; guru masih berpandangan, 'kekerasan' yang dilakukan dapat memicu lahirnya 'spirit dan kemauan' belajar anak. Dampaknya, proses pembelajaran masih menggunakan pendekatan threats of violence. Oleh karena itu penting ditingkannya motivasi intrinsik kompetensi guru melalui re-awareness terhadap potensi personal guru dengan penguatan apresiasi diri secara natural. Dikuatkannya motivasi ekstrinsik melalui penyehatan sistem manajerial keorganisasian melalui pemberian apresiasi terhadap kinerja guru. Selain dari itu, penting pula untuk ditingkatkannya layanan trilogi+1 pembelajar; konsep humanis yang memperlakukan guru, peserta didik, dan orangtua sebagai pelaku yang sama-sama aktif; koordinatif, komunikatif, dan apresiatif terhadapt setiap pencapaian pengetahuan yang didapatkan, serta menjadikan ilmu pengetahuan sebagai objek dan media pengembangan mentalitas peserta didik (manusia).
\end{abstract}

Kata kunci: humanisasi, pendidikan, pendidik dan peserta didik

\begin{abstract}
This study is conducted to analyze the pattern of human relationships between educators and learners in the educational process, to empirically prove the humanity behavior of educators to learners in the city of Malang. Furthermore, researchers give humanity quality improvement concepts offer to the educators in the educational process in the city of Malang. The approach of the research is done by using phenomenological qualitative research. The instruments used in the research are indepth interview, documentation and observation. The model of the analysis is using Miles and Huberman, and grand theory from Freire humanization theory. Based on the results of the analysis, it can be described that the humanity conduct of educators to learners in the educational process of SDN X and SDN Y in Malang have paradigmatic problem in which the teachers still holds the view that 'violence' could lead to the birth of 'spirit and willingness' of children's learning. The impact of the view is showing that the learning process is still using threats of violence approach. The concept of this research is to improve the intrinsic motivation of teacher competence through re-awareness of personal potency by strengthening the nature of teacher appreciation by themselves, strengthens extrinsic
\end{abstract}


motivation through organizational restructuring managerial system through the provision of an appreciation of the teacher's performance, improve the service trilogy +1 learners which using humanist concept that treats teachers, learners, and parents as active actors, coordinative, communicative, and appreciative on every achievement of the gained knowledge, and make science as objects and mentality development media for learners (human).

Key words: humanization, education, educators and learners

\section{PENDAHULUAN}

Konsep pendidikan humanis merupakan konsep nilai yang lebih menitikberatkan pada nilai-nilai kemanusiaan peserta didik. Dalam konteks pendidikan di Indonesia, cara pandang ini secara aplikatif belum dapat diterapkan dengan maksimal, sehingga selalu melahirkan masalah-masalah kemanusiaan. Tujuan dasar dari pendidikan humanis adalah sebagai wujud 'perlawanan' terhadap pola-pola pendidikan yang dominan mekanistik, reduksionistik, materialistik, atau memiliki kecenderungan untuk mereduksi manusia atas potensi-potensi kemanusiaanya (Zaini, 2014: 88). Namun demikian, humanisasi pendidikan tentunya bukan semata-mata karena adanya kebutuhan evaluasi dan refleksi dalam praktik pendidikan, tetapi secara praktis konsep ini masih marjinal dalam pelaksanaanya selama ini. Misalnya, pendidikan 'gaya bank,' metode 'hadap masalah,' 'kontradiksi guru-murid,'yang merupakan problem elementer sekaligus klasik dalam konsep pendidikan Freirean, masih sangat asing dan banyak disalah-mengerti (Shor dan Freire, 2001: ix). Persoalan yang selalu mengemuka, yakni: apakah pendidikan telah benarbenar mendorong pada terwujudnya nilainilai kemanusiaan? Apakah pola humanisme human telah menjadi landasan utama dalam praktik pendidikan?

Akhir-akhir ini tindakan kekerasan dalam pendidikan semakin marak terjadi di belahan bumi nusantara. Sebagaimana yang termuat di dalam situs web (media pendidikan.info/2010/09, 1) kota Malang, disebutkan, guru melakukan tindak kekerasan terhadap siswa SD. Dinda (korban) siswa kelas IV sebuah SD swasta ternama di kecamatan Lawang,-yang kronologis kejadiannya adalah ketika Dinda sedang mengerjakan pekerjaan rumah (PR) dikelas dipukul oleh guru kelasnya sampai memar dirahang kanannya. Selain dari kasus tersebut juga terjadi kasus, sebagaimana dimuat (surabaya.tribunnews.com, 6/09/2014, 2), penganiayaan SCL, siswa kelas 5 salah satu SDN di kota Malang, yang dilakukan oleh oknum guru setempat.

Tentu kasus-kasus seperti di atas bukan satu-satunya, tidak hanya dengan kekerasan secara fisik, bahkan juga dilecehkan secara seksual. Jika hal tersebut tidak secara cepat dan tepat mendapatkan penanganan, tentu hal ini akan memperburuk proses terbentuknya mentalitas anak. Pastinya, akan menghambat kualitas out put pendidikan anak di masa yang akan datang. Sebagaimana dikatakan Merdeka Sirait (ketua Komnas Perlindungan Anak), bahwa kekerasan pada anak sudah sangat mengerikan dan bisa dikatakan pada tahap darurat (Nasional.kompas.com/ read/ 2014 /05/ 07). Ini menggambarkan bahwa masalah ini tidak hanya menyangkut masalah proses pendidikan di sekolah, tetapi menyangkut masalah kemanusian secara umum. 
Menurut data yang terhimpun melalui media online (antaranews.com/-Jumat, 25/ 02/2011), bahwa kasus kekerasan terhadap anak dan perempuan yang ditangani Kantor Pemberdayaan Perempuan dan Perlindungan Anak (KP3A) Malang, dalam tiga tahun terakhir terus mengalami peningkatan. Pada tahun 2008 jumlah kasus tersebut mencapai 212 (kasus), 2009 meningkat menjadi 222 kasus dan 2010 bertambah lagi menjadi 268 kasus.

Dari kasus-kasus tersebut, menggambarkan bahwa; 1) kesadaran dalam proses pendidikan mendapatkan perhatian yang lemah, 2) problem kesadaran masyarakat belum mencapai tahapan "kesadaran kritis" (critical consciousness). Oleh karena itu, masalah kesadaran dalam dunia pendidikan memiliki peranan yang sangat penting, sehingga apabila kesadaran ini lemah maka kecenderungan lahirnya tindakan kekerasan tidak bisa dipungkiri. Sebagai dampaknya, setiap kasus yang terjadi selalu memposisikan masyarakat bawah sebagai yang tertindas, tidak dapat melawan penindasan, meminjam istilah Paulo Freire, 'mereka' telah tenggelam ke dalam culture of silent (Murtiningsih, 2004: 22). Dalam artian, kondisi korban berada dalam kondisi tertekan, dan tidak mampu menyampaikan seluruh aspirasinya karena otoritas 'penguasa' yang sangat dominatif. Dalam buku Freire, yang berjudul Pendidikan Kaum Tertindas, Freire menuliskan:

Itulah sebabnya mengapa kedermawanan hati mereka (penindas) palsu. Harkat kamanusiaan telah dianggap semacam 'barang', dan mereka memilikinya sebagai hak istimewa, sebagai kekayaan warisan. Dalam kesadaran kaum penindas, humanisasi ‘orang lain', yakni seluruh masyarakat dianggap sebagai subversif bukan sebagai usaha untuk menjadi manusia seutuhnya (Freire, 1995: 33).

Pada ranah ini seorang guru senantiasa menjalankan kebijakan pendidikan sesuai dengan text guidance, tak ubahnya praktik sistem pendidikan domesticating yang bersifat preskriptif (Freire, 2005: 176), yakni, layaknya seorang dokter yang memberikan resep terhadap para pasien. Murid terkesan dianggap sebagai manusia pengidap penyakit yang setelah didiagnosa, selanjutnya diberikan resep obat untuk ditebus di Apotik. Pada gambaran analogi logika tersebut tampak adanya proses pasif seorang guru terhadap murid yang tidak mencerminkan dialogika pembelajaran serta menutup segala ruang pemberdayaan humanisme, baik bagi sang guru begitu juga bagi seorang murid.

Bila sudah demikian, benarkah pendidikan telah membawa anak didik pada wilayah yang menghargai humanisme, atau justru telah menjungkir-balikkannya pada wilayah dehumanisme,yang menganggap peserta didik layaknya barang yang siap dibentuk, dicetak sesuai dengan kemauan pemiliknya. Bukankah anak didik juga manusia yang bersama guru dalam proses menjadi dirinya, bukan menjadi seperti orang lain? Secara umum hal inilah tidak menjadi perhatian utama oleh para pendidik, sehingga mengakibatkan rendahnya kualitas kemanusiaan peserta didik.

\section{Paradigma humanisasi pendidikan Freire}

Eksistensi manusia diciptakan ke dunia merupakan manivestasi dari keesaan dan kekuasaan Tuhan. Manusia menjalani dinamika kehidupan dengan cara aktualisasi dari segenap potensi yang dimiliki dan potensi tersebut yang menjadi landasan dalam setiap penetrasi sosial yang dijalani. 
Potensi yang manusia miliki harus terlebih dahulu diidentifikasi dan secara lebih lanjut diupayakan dengan jalan dialogis dan sinergis terhadap realitas alam semesta beserta isinya. Hal ini ditujukan untuk mewujudkan harmoni kehidupan yang kodrati sesuai ketentuan Tuhan.

Humanisasi pendidikan, menurut Zaini (2014: 88) merupakan pola pemanusiaan yang terkonstruk dalam sistem nilai-nilai kebijakan pendidikan. Hal ini mendasarkan pada sebuah konsep menjunjung tinggi aspek kemanusiaan serta merupakan bagian dari kecenderungan humanistik universal, yang mengejawantahkan diri dalam pendidikan, ilmu-ilmu sosial dan filsafat ilmu pengetahuan. Humanisasi adalah satu segmen gerakan yang lebih besar, yang mengaku hendak berlaku adil terhadap kemanusiaan manusia serta berusaha membangun ilmu pengetahuan tentang manusia.

Oleh karena itu untuk menjaga harmoni yang baik dalam kehidupan dibutuhkan sebuah proses pendidikan yang humanis. Kaitannya dengan hal tersebut, Freire merupakan tokoh filosofis dan humanis yang mendorong manusia untuk terbebaskan dari berbagai tekanan (Muri'ah, 2011: 135-136). Visi tersebut berpijak pada penghargaan manusia dan pengakuan bahwa harapan dan masa depan yang disampaikan pada kaum tertindas tidak sekadar menjadi hiburan, sebagaimana juga bukan untuk terus menerus mengecam dan menentang kekuatan objektif kaum tertindas. Bagi Freire, penindasan, apapun nama dan alasannya, adalah tidak manusiawi, sesuatu yang menafikan harkat kemanusiaan. Dehumanisasi bersifat ganda, dalam arti, terjadi atas diri mayoritas tertindas dan juga atas diri penindas yang keduanya menyalahi kodrat manusia sejati.

\section{Kekerasan dalam pendidikan}

Realitas sebaliknya dari humanisasi pendidikan adalah dehumanisasi pendidikan. Istilah dehumanisasi ini bisa muncul dalam berbagai bentuknya, termasuk dalam bentuk kekerasan secara umum. Kekerasan dalam pendidikan didefinisikan sebagai sikap agresif pelaku yang melebihi kapasitas kewenanganya dan menimbulkan pelanggaran hak bagi si korban, baik hak secara fisik atau psikis. Secara kategoris, kekerasan dibedakan dengan kriminalitas, karena hukum mengenai kriminalitas telah diatur sendiri sebagaimana hukum yang berlaku.

Secara teoritis, Assegaf, (2004: 37) menyatakan; perilaku kekerasan dapat dibedakan sebagai berikut:

a. Kekerasan tingkat ringan, yakni berupa potensi kekerasan (violence as potential). Pada tingkat ini kekerasan yang terjadi umumnya berupa kekerasan tertutup (covert), kekerasan defensif, unjuk rasa, pelecehan martabat, dan penekanan psikis.

b. Kekerasan tingkat sedang, yang berupa perilaku kekerasan dalam pendidikan itu sendiri (violence in education). Indikator kekerasan tingkat ini mencakup: kekerasan terbuka (overt), terkait dengan fisik, pelanggaran terhadap aturan sekolah/ kampus, serta membawa simbol dan nama sekola

c. Kekerasan tingkat yang ketiga adalah kekerasan tingkat berat, yakni tindak kriminal (criminal action). Pada tingkat ini kekerasan berbentuk kekerasan offensive, ditangani oleh pihak yang berwajib, ditempuh melalui jalur hukum, dan berada berada di 
luar wewenang pihak sekolah/ kampus.

Kekerasan dalam pendidikan diasumsikan terjadi sebagai akibat kondisi tertentu yang melatarbelakanginya, baik faktor internal dan eksternal, dan tidak timbul begitu saja, melainkan dipicu oleh suatu kejadian. Kondisi (antecedent variable), faktor (independent variable) dan pemicu (intervening variable) tindak kekerasan dalam pendidikan (dependent variable) terangkai dalam hubungan yang bersifat spiral, dapat muncul sewaktu-waktu, oleh pelaku siapa saja yang terlibat dalam dunia pendidikan, sepanjang dijumpai adanya pemicu kejadian.

Berkenaan dengan hal tersebut, berikut dikutip diagram spiral kekerasan yang dikutip di dalam buku Assegaf, (2004: 79-80) sebagai berikut:

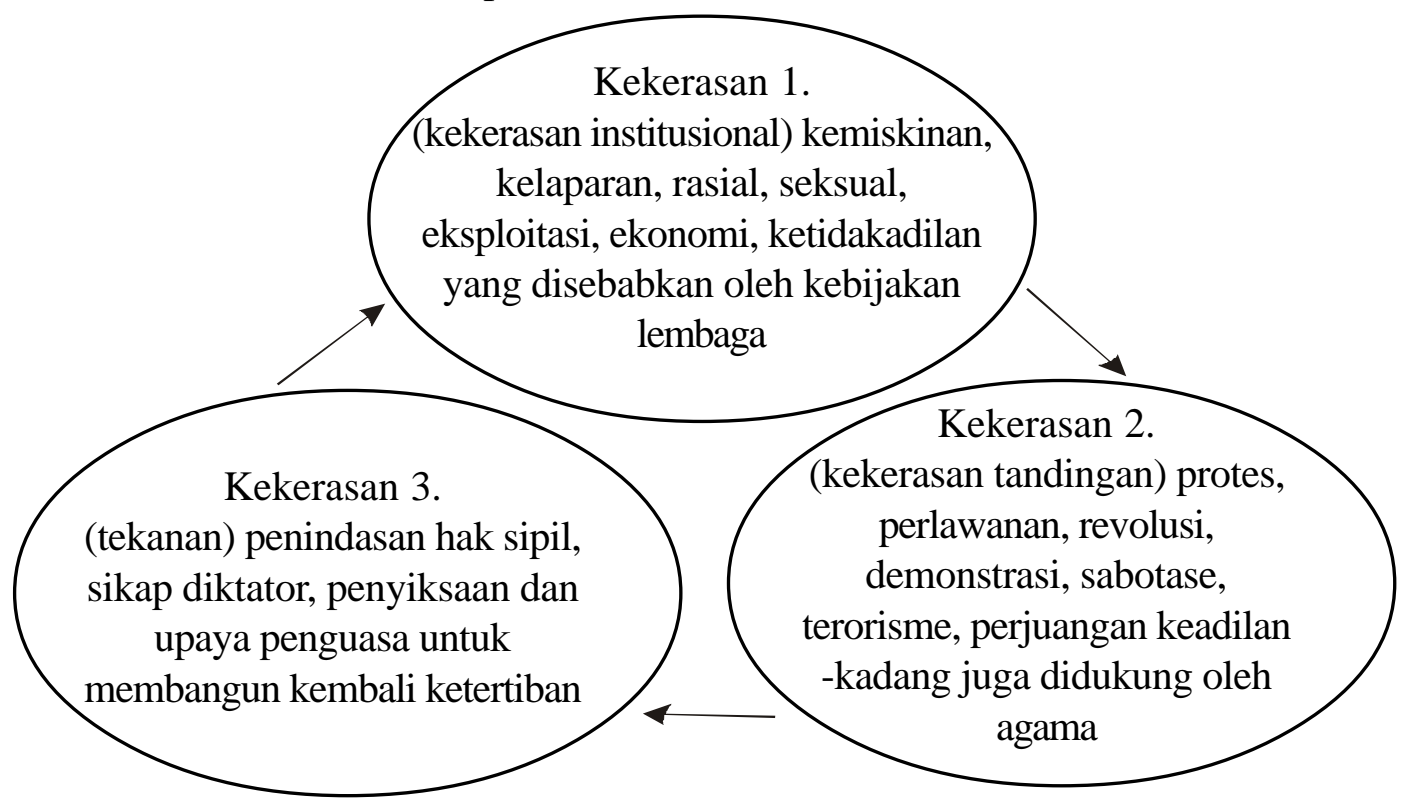

Gambar 1. Diagram spiral kekerasan

(Sumber: Assegaf, 2004)

Diagram spiral kekerasan di atas, bermula dari kekerasan ke-1 atau kekerasan institusional, yakni kekerasan yang ada dalam peraturan/ kebijakan lembaga/ sistem yang mendorong manusia ke arah kondisi yang tidak manusiawi, misalnya menerima penghinaan, ketidakadilan dan keadaan tanpa harapan. Selanjutnya kekerasan ini menimbulkan bentuk kekerasan ke-2 yakni kekerasan tandingan yang muncul sebagai reaksi terhadap kekerasan yang pertama. Bentukbentuknya bisa berupa kerusuhan, revolusi, tawuran, dan tindakan kriminalitas lainnya.
Kekerasan ke-3 adalah tekanan atau kondisi tertekan (repression) yang muncul sebagai respon atas kekerasan ke-2, yang sering menuntut kehadiran aparat kepolisian dan militer dalam jumlah yang banyak.

\section{METODE}

Pendekatan kualitatif dengan desain fenomenologis, digunakan untuk mencapai tujuan tersebut dari penelitian ini. Teknik pengumpulan data menggunakan interview, dokumentasi, dan observasi. 
Sumber data utama dalam penelitian ini adalah kata-kata lisan melalui interview, tulisan melalui data dokumentasi, tindakan melalui data hasil observasi. Sedangkan data sekunder dalam penelitian ini, diantaranya; UUD 1945, UU. Sisdiknas No. 20 tahun 2003, UU. No. 14 tahun 2005, KTSP, PP. 19 tahun 2005 tentang Standar Nasional Pendidikan, dan UU. No. 35 tahun 2014 tentang perlindungan anak.

Sedangkan teknik analisis data yang digunakan adalah teknik analisis interaktif Miles-Hubberman yang dilakukan melalui empat tahap, yaitu: pengumpulan data, reduksi data, display data, serta penarikan kesimpulan dan verifikasi. Penelitian ini dilaksanakan di (SDN X dan SDN Y) kota Malang tahun 2016.

\section{HASIL DAN PEMBAHASAN}

\section{Perilaku humanitas pendidik di kota Malang}

Dalam undang-undang Republik Indonesia nomor 20 Tahun 2003 bab I pasal 1 ayat 1 disebutkan bahwa Pendidikan adalah usaha sadar dan terencana untuk mewujudkan suasana belajar dan proses pembelajaran, agar peserta didik secara aktif mengembangkan potensi dirinya untuk memiliki kekuatan spiritual keagamaan, pengendalian diri, kepribadian, kecerdasan, akhlak mulia sera keterampilan yang diperlukan dirinya, masyarakat, bangsa dan negara.

Dalam proses pendidikan melibatkan banyak hal, diantaranya adalah pendidik sebagai kunci kendali utama, peserta didik sebagai mitra terlibat, dan interaksi antara pendidik dengan peserta didik. Pendidik adalah orang yang membantu agar anak didik mampu menuju kearah kedewasaan, dalam pembelajaran baik dalam bentuk formal, non formal maupun informal.

Untuk mencapai keberhasilan dalam pendidikan dibutuhkan peran pendidik sebagai pemicu terjadinya proses pembelajaran yang lebih baik. Karena pendidik merupakan kunci utama terhadap kesuksesan pendidikan. Untuk itu seorang pendidik harus memiliki kompetensi, yakni: kompetensi pedagogis, personal, sosial dan profesional. Dengan kompetensi tersebut maka pendidik, sebagaimana disebtkan, dalam UU No. 20 tahun 2003 pasal 1 , hendaknya mampu menjadi tenaga kependidikan yang berkualifikasi sebagai guru, dosen, konselor, pamong belajar, widyaswara, tutor, instruktor, fasilitator, dan sebutan lain yang sesuai dengan kekhususannya, serta berpartisipasi dalam menyelenggarakan pendidikan.

Kota Malang sebagai kota yang mendapatkan sebutan 'Kota Pendidikan,' merupakan kota yang sarat dengan prestasi pendidikan seiring dengan sistem dan dinamika kependidikannya. Meski demikian Malang seringkali mendapatkan sorotan yang cukup tajam, terutama terkait dengan persoalan-persoalan kependidikan, termasuk diantaranya masih adanya persoalan kekerasan dalam pendidikan. Dalam hal ini tentu yang menjadi tertuduh pertama adalah seorang pendidik (guru). Pendidik tentu dapat dibenarkan mendapatkan sasaran fokus utama, mengingat pendidiklah yang paling bertanggungjawab dalam proses pendidikan di sekolah. Oleh karena itu, bila terjadi kekerasakan dalam pendidikan, maka yang pertama kali ditanyakan adalah 'siapa guru'nya, bukan 'siapa kedua orangtuanya’. Bila demikian, seorang guru benar-benar menempati posisi yang strategis dalam dunia pendidikan. Adanya empat kompetensi di atas, menggambarkan profesionalitas guru dalam mengajar dan 
mendidik di sekola Bukan malah sebaliknya guru melakukan kekerasan dalam pendidikan, apapun alasan dan motifnya.

Menurut data yang didapatkan peneliti di SDN X Malang, terkait dengan perilaku dehumanitas pendidik di Malang, bahwa pendidik pada kedua sekolah tersebut terkategorikan pada pendidik yang dehumanis. Hal ini berdasar pada pernyataan hasil interview pada tanggal, 24 Maret 2016 dengan guru SDN X Malang:

Saya pernah kepikir, mengapa anakanak susah diatur, sehingga saya menggunakan model ancaman, yang saya duga efektif. Karena menerapkan empat kompetensi dalam konteks humanitas itu tidak muda Sulit mengendalikan anak dengan jumlah banyak dalam 1 kendali. Saya sering menghadapi komplen dari wali murid. Dulu pernah ada kasus kekerasan, yaa terkait dengan ‘kenakalan’ peserta didik.

Dari pernyataan pendidik di atas tergambar bahwa perilaku humanitas pendidik, pada salah satu sekolah di maksud dalam 'masalah'. Masalah yang dimaksud adalah terkait dengan, 1 . pola penyajian materi, 2. pola pelayanan terhadap peserta didik, 3. serta respon balik terhadap peserta didik.

Ketiga hal di atas merupakan momentum yang hendaknya terjadi secara humanis pada setiap saat di dalam kelas, sehingga kelas betul-betul menjadi tempat yang menyenangkan bagi setiap peserta didik. Atau dapat disebut juga dengan pembelajaran berbasis PAIKEM, yakni pembelajaran aktif, inovatif, kreatif, efektif dan menyenangkan.

Akan tetapi bila sebaliknya, maka yang terjadi, kelas hanyalah menjadi tempat formal pembelajaran, tetapi tidak mampu menggugah tumbuhnya kesadaran bagi peserta didik. Sikap yang muncul adalah sikap dehumanis, baik dari pendidik dan juga peserta didik. Sikap dehumanis pendidik dalam hal ini tentu sangat membahayakan bagi setiap peserta didik. Apalagi melihat dan mendengar statamen ancaman yang selalu disampaikan oleh pendidik, “..... anak-anak, duduklah kembali pada tempat duduknya, atau akan bu guru berikan hukuman...!!”.

Pernyataan ancaman dalam hal ini sudah dapat dipastikan bukan merupakan metode yang dapat dibenarkan dalam teori-teori pendidikan. Karena secara humanis ancaman tidak cenderung membawa dampak perkembangan mental yang lebih baik, namun sebaliknya hanya dapat memberikan tekanantekanan psikis, sehingga anak bukan semakin takut terhadap pernyataan ancaman guru, tetapi semakin 'berani' dan selalu ingin membuktikan hukuman dan jenis hukuman berikutnya.

Ketika anak mendapatkan ancaman dari guru kelas, tampak anak didik tidak langsung kembali ke tempat untuk duduk, sebaliknya anak semakin menjauh dari tempat duduk, bahkan semakin sulit terkendalikan. Fenomena tersebut semakin memberikan gambaran bahwa guru belum memiliki metode pembelajaran yang humanis, sehingga yang tampak adalah model pembelajaran dehumanis. Dikatakan Freire:

Bagaimana bisa saya masuk ke dalam suatu dialog jika saya selalu memandang bodoh pada orang lain dan selalu lupa mawas diri pada kelemahan saya sendiri? Bagaimana bisa saya masuk ke dalam suatu dialog jika saya menganggap diri saya sebagai kasus yang terpisah dari 
orang lain-sekedar 'nya' di mana saya tidak melihat 'adalah' lain.

Bertolak dari pernyataan Freire dan mengkaji statemen guru di area penelitian, bahwa terdapat beberapa hal penting untuk dikritisi sebagai berikut.

1. Mengapa belajar harus dengan cara duduk?

2. Mengapa tidak digunakan model pembelajaran berbasis game?

3. Mengapa harus menggunakan ancaman bila memang ada model pembelajaran yang lebih dialogis..?

4. Mengapa tidak membiarkan peserta didik untuk lebih kreatif sehingga tidak harus dihalau untuk duduk manis menyimak ceramah guru..?

5. Mengapa tidak menggunakan metode pembelajaran yang interaktif sehingga pembelajaran akan lebih efektif..?

Itulah persoalan-persoalan yang sering mengemuka dan tidak sempat terpikirkan oleh sebagian besar pendidik di sekola Keterbatasan pemahaman dalam hal ini cenderung memunculkan sikap yang tidak humanis, bahkan tempramen di hadapan peserta didik, sehingga muncul tindakantindakan kekerasan dalam pendidikan. Sebagaimana yang pernah terjadi pada salah satu SDN di kecamatan Blimbing kota Malang. Dinarasikan oleh kepala sekolah SDN Y tentang tindakan kekerasan yang terjadi di sekolahnya:

Anak saat itu bermain, naik bangku, diingatkan oleh anak kelas II, "mas gak boleh lhoo" anak yang diingatkan otomatis emosional,..”saya kok diingatkan oleh anak di bawah saya”. Akhirnya didorong kemudian jatuh, nangis.. akhirnya salah satu guru datang memarahinya, akhirnya misoh anak yang emosional itu ke gurunya. Kemudian secara spontan anak tersebut ‘diginikan’ (responden memperagakan cara menempeleng)

oleh gurunya. Mungkin saja guru itu spontan, guru kok dipisue. Maksudnya, biar selanjutnya tidak terulang lagi. Akhirnya anaknya lapor ke budhenya yang waktu itu menjemput, budhenya lapor suaminya, dan selanjunya melaporkannya ke pihak yang berwajib.

Tindakan reflek atau sengaja melakukan kekerasan terhadap anak di lingkungan sekolah, merupakan tindakan yang sama-sama melanggar ketentuan cara mendidik anak. Profesionalitas dalam hal ini menjadi suatu pertanyaan yang serius. Bila guru tersebut sudah tersertifikasi, maka yang menjadi pertanyaan, bagaimana guru tersebut dapat lolos mengikuti sertifikasi? secara pasti dalam hal ini sangat berkaitan erat dengan kompetensi guru, terutama kompetensi personal dan sosialnya.

Dengan demikian, mengkaji realitas kasus kekerasan (dehumanitas) terhadap peserta didik di atas, adalah tidak pada posisinya guru melakukan tindakan kekerasan dalam pendidikan. Menyadur dari pandangan Freire, bahwa kekerasan merupakan tindakan yang tidak lebih dari hanya sekedar investasi mental, yang pada akhirnya juga akan melahirkan kekerasan berikutnya. Dalam artian, bahwa kekerasan yang dilakukan oleh guru dengan berbagai jenis dan motifnya, tidak cukup mampu malahirkan nilai perilaku positif bagi peserta didik. Tetapi sebaliknya hanya mampu melahirkan kekerasan yang sama dan itu tertanam di dalam setiap peserta didiknya. Jika hal ini yang terjadi dalam praktik kependidikan di sekolah, maka yang terjadi pendidikan bagi peserta didik di tingkat dasar (SD) di kota Malang hanya mampu melahirkan orang-orang pintar dan cerdas secara kognitif, tetapi tidak mampu 
melahirkan peserta didik berkarakter pengasih dan penyayang terhadap sesama.

Dalam konsep pendidikan gaya bank, pengetahuan merupakan sebuah anugerah yang dihibahkan oleh mereka yang menganggap dirinya berpengetahuan kepada mereka yang dianggap tidak memiliki pengetahuan apa-apa. Menganggap bodoh secara mutlak pada orang lain, sebuah ciri dari ideologi penindasan, berarti mengingkari pendidikan dan pengetahuan sebagai proses pencarian. Guru menampilkan diri di hadapan murid sebagai orang yang berada pada pihak yang berlawanan; dengan menganggap murid mutlak bodoh, maka secara otomatis ada upaya pengukuhan keberadaan dirinya sendiri. Para murid yang bagaikan 'budak terasing' dalam dealektika Hegel, menerima label kebodohan sebagai pengesahan keberadaan sang guru tetapi, tidak seperti budak, murid tidak pernah menyadari bahwa murid mendidik gurunya.

Paradigma analitis yang digambarkan Freire di atas sebenarnya merupakan permasalah yang cukup rumit ketika hal tersebut terjadi dan menjadi virus di dalam mindset para guru. Karena ketika hal tersebut menjelma di dalam cara berpikir guru, maka yang terjadi, guru mengkultuskan dirinya sebagai yang lebih segala-galanya dibanding peserta didik, sehingga guru merasa memiliki otoritas tak terbatas di hadapan peserta didik, termasuk guru leluasa melakukan tindakan kekerasan terhadap peserta didik.

Dengan demikian, perilaku guru sebagai pendidik di (SDN Y dan SDN X) Malang, belum menggambarkan perilaku mendidik dengan cara yang humanis, sebaliknya dengan cara dehumanis; model pembelajaran yang digunakan masih bersifat retoris-naratif, dan tidak menjadikan peserta didik sebagai pusat pembelajar.

\section{Tawaran konsep meningkatkan humanitas pendidik di kota Malang}

Perilaku humanitas pendidik merupakan sifat mutlak yang tidak dapat ditoleransi pada pendidik di setiap satuansatuan pendidikan. Hal ini menjadi penting untuk diseriusi mengingat dunia pendidikan berkaitan erat dengan nasib dan masa depan peserta didik, yang semuanya bermuara pada potensi generasi dalam sebuah bangsa.

Oleh karena itu meningkatkan kualitas humanitas pendidik dalam proses pendidikan merupakan suatu yang tidak dapat ditawar-tawar lagi. Dalam artian, seorang guru tidak saja mengupayakan diri untuk dapat menerapkan standarstandar regulasi yang tertuang di dalam Undang-undang Guru dan Dosen (UU.GD) No. 14 tahun 2005, Peraturan Pemerintah tentang Standar Nasional Pendidikan (PP.SNP) Nomor 19 tahun 2005, dan berbagai peraturan Kementrian Pendidikan lainnya beserta Petunjuk Pelaksanaan dan Petunjuk Teknisnya (Juklak-Juknis), tetapi jauh lebih dan sangat penting dari hal tersebut adalah seorang pendidik mengetahui dan menyadari secara 'nurani' bahwa dirinya adalah seorang guru yang memiliki tugas luhur memberikan manfaat kepada peserta didiknya (khususnya) dalam keadaan apapun.

Peningkatan kualitas kemanusiaan dalam proses pendidikan hendaknya dapat dilihat dari dua sudut pandang, yakni sudut pandang pendidik dan sudut pandang peserta didik. Sebagaimana disampaikan Freire dalam bukunya, "pendidikan kaum tertindas", bahwa: antara pendidik dan peserta didik, keduanya merupakan korban dari dehumanisasi yang sistemik, sehingga menuntut keduanya untuk dilakukan refresh kesadaran sampai pada perilaku riil dalam keseharian. Dalam hal ini Freire 
mengategorikan kesadaran menjadi empat level kesadaran atau yang disebut dengan empat arkeologi `kesadaran`:

Pertama, kesadaran semi intransitif. Kesadaran ini tidak dapat terobyektifikasikan ke dalam sebuah fakta. Dalam artian kaum dehumanis, dalam hal ini peserta didik, kurang memiliki asumsi hirarkhis, sehingga realitas hidup adalah superealitas (sesuatu yang terbatas dengan realitas obyektif). Tindakan person pada level ini cenderung fatalistik, magis-defensif atau magis-terapis. Ritual-ritual keagamaan yang dilakukan oleh person yang awalnya sebagai dogma agama (asli atau sinkretik), namun perlahan beralih menjadi tradisi biasa.

Kedua, bentuk semi kesadaran transitif naif (naive transitivity). Bertolak dari kesadaran semi intransitif, selnjutnya berkembang menjadi kesadaran transitif naif (naive transitivity). Perkembangan ini dimotori oleh tindak kekerasan dan penindasan yang terjadi, sehingga pada titik kulminasinya person mulai sadar bahwa dirinya tertindas (ditindas) dan selanjutnya merencanakan perlawanan sebagai gerakan protes.

Ketiga, kesadaran transitif naif. Pada tahap ini person sudah mampu menganalisis dan merefleksikan masalah penindasan yang ada, sadar akan keadaannya, akan tetapi belum mampu menyampaikan temuantemuannya atas dasar 'kepentingannya'. Pada tahap ini, person memahami bahwa dirinya berada pada posisi dependen.

Keempat, kesadaran transitif kritis atau juga dapat disebut kesadaran kritis, sebuah kondisi yang menggambarkan bahwa person telah mampu secara kritis menyampaikan pandangan-pandangannya tentang masalah yang dihadapi di sekitarnya. Memulai memisahkan dirinya dengan kelompok penindas, dan selanjutnya mengambil langkah taktis upaya membebaskan dirinya.

Dari empat tahapan kesadaran di atas merupakan konsep yang dilatarbelakangi oleh sejarah Amerika Latin, di mana Freire hidup dan memperjuangkan hak-hak kaum proletar. Freire mengatakan bahwa "perubahan kesadaran dari semi transitif menuju full kesadaran, merupakan kesempatan yang mampu menginspirarasi kesadaran para elit penguasa, sehingga menjadi kesempatan pula bagi kelompok kritis-progresif untuk melakukan humanisasi bagi kaum tertindas. Proses humanisasi terhadap kaum tertindas pada akhirnya mampu menjadi suatu gerakan massif bersamaan dengan munculnya kesadaran kritis pada kelompok kecil intelektualis.

Identifikasi tahapan dan analisis kesadaran inilah yang dimanfaatkan Fiere, dalam rangka membangun iklim dialogisfredomis, yang mampu memberikan garansi mencapai pada level kesadaran kritis.

Pada analisis filosofis terhadap pemikiran Freire di atas, dapat dikontektualisasikan ke dalam realitas permasalahan humanisasi pendidikan yang ada di kota Malang. Istilah 'penguasa' pada analisis di atas, pada dasarnya adalah sama dengan guru, yang ketika berhadapan dengan peserta didik bersikap dan bersifat otoritatif. Sedangkan istilah 'kaum tertindas' adalah sama dengan peserta didik yang lemah, yang sama sekali tidak memiliki otoritas apapun di hadapan guru. Dalam hal ini peserta didik dimaksud, menurut Freire, berposisi pada level kesadaran semi intransitif. Dalam arti, peserta didik terjebak ke dalam klaim bahwa peserta didik sudah merupakan taqdirnya untuk 'manut' sepenuhnya terhadap guru, tanpa memiliki hak apapun untuk konfirmasi kepada guru, sehingga dengan sendirinya peserta didik terjebak di dalam 'budaya bisu'. 
Sedangkan peserta didik yang menjadi korban kekerasan dalam pendidikan, sebagaimana yang terjadi di SDN X ataupun yang terjadi di SDN Y merupakan peserta didik yang memiliki tingkat kesadaran semi transitif, bahkan memasuki tingkat kesadaran transitif naif. Dalam arti, peserta didik telah memiliki spirit pembebasan atas dominasi yang 'dilakukan' oleh gurunya, sehingga muncullah sikap dominan otoritatif dari seorang guru, walaupun dalam hal ini peserta didik tetap pada posisi dikorbankan.

Cara pandang Freire dalam konteks masalah pendidikan di atas, tidak dalam arti membolehkan atau mentoleransi perlawanan murid terhadap guru sebagai bentuk 'protes'. Tetapi yang dapat dipahami bahwa tindakan kekerasan dalam bentuk apapun dan dari level manapun tidak dapat dibenarkan keberadaannya, karena bertentangan dengan nilai-nilai humanitas itu sendiri. Nilai-nilai humanitas dalam setiap diri manusia merupakan hal yang mutlak dan tidak dibenarkan siapapun mengusiknya.

Oleh karena tindakan dominatif dan de-dominatif (protes dalam bentuk perlawanan), baik sebagai pelaku ataupun sebagai korban, keduanya merupakan korban dari nilai-nilai kemanusiaan yang tercederai, sehingga keduanya sama-sama membutuhkan penyadaran secara intensif. Dengan demikian dibutuhkan sebuah konsep trobosan, sebagai tawaran perilaku humanis pendidik terhadap peserta didik dalam proses pendidikan di kota Malang.

a) Meningkatkan motivasi intrinsikekstrinsik dari kompetensi guru

Dengan meningkatkan motivasi intrinsik, seorang guru diharapkan mampu meningkatkan kinerjanya dalam upaya meningkatkan kualitas pendidikan di sekolah, khususnya pada tingkatan sekolah dasar (SD) di kota Malang. Motivasi intrinsik seorang guru, mampu meningkatkan dedikasinya dalam melaksanakan tugas dan kewajibannya sebagai seorang guru. Motivasi intrinsik merupakan dorongan dari dalam diri seorang guru, ditopang melalui penguatan-penguatan apresiasi diri secara natural, sehingga seorang guru tampil sebagai mahluk sosial yang elegan dan menyenangkan.

Motivasi intrinsik ini mampu melahirkan 'kenikmatan,' tertarik, dan merasa senang menjalankan tugasnya. Selain dari hal tersebut guru juga merasa tertantang untuk menghasilkan kinerja yang berkualitas dalam bentuk kreatifitas tinggi. Semakin tinggi motivasi intrinsik kerja guru, akan mendorong peningkatan kompetensi, yang berujung pada peningkatan kompetensi dirinya. Tentu dalam hal ini, empat kompetensi yang menjadi standar acuan dalam profesi keguruan yang ada, secara otomatis dapat terpenuhi, khususnya kompetensi sosial yang didukung dengan kompetensi kepribadian. Kompetensi guru yang baik, akan memberikan pengaruh positif pada berbagai pelaksanaan fungsi dan tugas seorang guru. Apabila guru telah mampu mencapai kompetensi pedagogik yang mantap, kepribadian yang luhur, sosial yang ramah serta profesionalitas yang stabil, maka persoalan dehumanisasi dalam pendidikan tidak akan dominan. Bahkan persoalan tersebut terentaskan sampai pada titik radikal kesadaran bahwa keberadaan manusia adalah untuk dimanusiakan.

Selain motivasi intrinsik juga motivasi ekstrirnsik. Dalam arti bahwa motivasi yang dari luar, dalam bentuk apresiasi melalui sistem manajerial satuan-satuan pendidikan di tingkat dasar, menjadi penting 
untuk disehatkan. Mengingat sistem manajerial kelembagaan dalam satuan pendidikan merupakan rangkaian effect yang selalu dapat memberikan penegasan link terhadap rangkaian effect berikutnya. Rangkaian di maksud bertalian kuat dengan kinerja seorang pendidik. Apabila sistem pengelolaan pendidikan menunjukkan mekanisme yang positif terhadap apresiasi kinerja guru, maka secara otomatis akan mampu melahirkan motivasi intrinsik. Dampaknya, kompetensi guru akan menguat, dan interaksi diri dan peserta didik akan lebih humanis. Dengan demikian, proses pendidikan akan sampai pada level pendidikan yang memanusiakan.

Kompetensi guru merupakan instrumen yang mampu menyajikan layanan terbaik kepada peserta didik. Kompetensi guru yang baik, akan memberikan positive effect pada setiap penyelenggaraan tupoksi guru, sehingga menjadi faktor yang turut mempengaruhi kinerja guru.

\section{b) Meningkatkan Pola Layanan Trilogi+1 Pembelajar}

Secara umum icon istilah dan ruang lingkup yang digunakan dalam dunia pendidikan selama ini adalah 'tri pusat pendidikan', dengan cakupan; sekolah, keluarga dan masyarakat. Tentu teori tersebut bersifat universal, sangat luas, bahkan tidak mampu menyentuh aspek yang riil dan kongkrit. Oleh karena itu, istilah yang lebih spesifik menyentuh ruang dan area pembelajaran, lebih tepatnya menggunakan re-teori / re-terminologi; "trilogi +1 pembelajar"

Tri pusat pembelajar merupakan tri logi ranah pendidikan yang selama ini kurang spesifik menjadi perhatian serius para pelaku pendidikan. Selanjutnya akan ramai menuai perhatian apabila telah muncul kasus, dan seluruh stakeholder pendidikan memiliki kepedulian yang tinggi terhadap pendidikan. Pada hal realitas tersebut hanyalah musiman dan sebelumnya jauh dari ranah konsistensi perhatian dan kepedulian publik.

Melihat dari realitas musiman perhatian dan inkonsistensi publik dalam mengawal tri pusat pembelajar di maksud, tentu hal ini akan menjadi masalah yang rumit dan komplek dalam dunia pendidikan. Pada akhirnya berbagai masalah pendidikan akan menjamur dan menjadi tidak mudah ditangani secara cepat.

Persoalan dehumanisasi dalam prosesproses pembelajaran seringkali menjadi masalah yang bersifat reguler dalam dunia pendidikan. Hal ini terjadi sepanjang tahun di berbagai tempat satuan-satuan pendidikan. Tentu masalah utamanya adalah tidak sinerginya di antara ke tiga komponen tersebut (tri pusat pembelajar), yakni Guru, Anak dan Orangtua. Dalam dunia pendidikan, ke tiga komponen tersebut memegang peranan yang penting (very significant). Ketiganya merupakan kunci penentu di dalam menjalankan visi besar pendidikan.

Sebagaimana yang tertuang di dalam tujuan pendidikan, tergambar nilai-nilai luhur dan sekaligus pengharapan besar yang tersemat di dalam setiap pelaku pendidikan. Pelaku pendidikan sebagaimana tri pusat pembelajar, sama-sama memiliki peranan yang saling bersambut dan saling mendukung. Ketiganya sama-sama bersinergi mewujudkan tujuan yang diusung, sehingga pada saatnya impian besar di atas tidak hanya menjadi sesuatu yang utopis, sebaliknya menjadi hal yang realistis. Apabila Freire mengatakan bahwa dalam sebuah proses pendidikan melibatkan tiga hal, yakni: pendidik, peserta didik dan ilmu pengetahun. Dalam arti pendidik, bersinergi dengan peserta didik, sama-sama sebagai 
subjek aktif, dan menjadikan Ilmu Pengetahuan sebagai objek pasif untuk selalu dapat dikembangkan sesuai perkembangan zaman. Di dalam trilogi atau peneliti menyebut tripusat pendidikan, yang menjadi subjek aktif adalah pendidik, peserta didik, sebagai mitra yang samasama berposisi sebagai pembelajar dan orangtua peserta didik sebagai mitra komunikasi yang mendukung terhadap proses terjadinya pembelajaran di sekola, sedangkan yang menjadi objek pasifnya adalah ilmu pengetahuan. Sebagaimana yang dapat digambarkan pada gambar berikut:

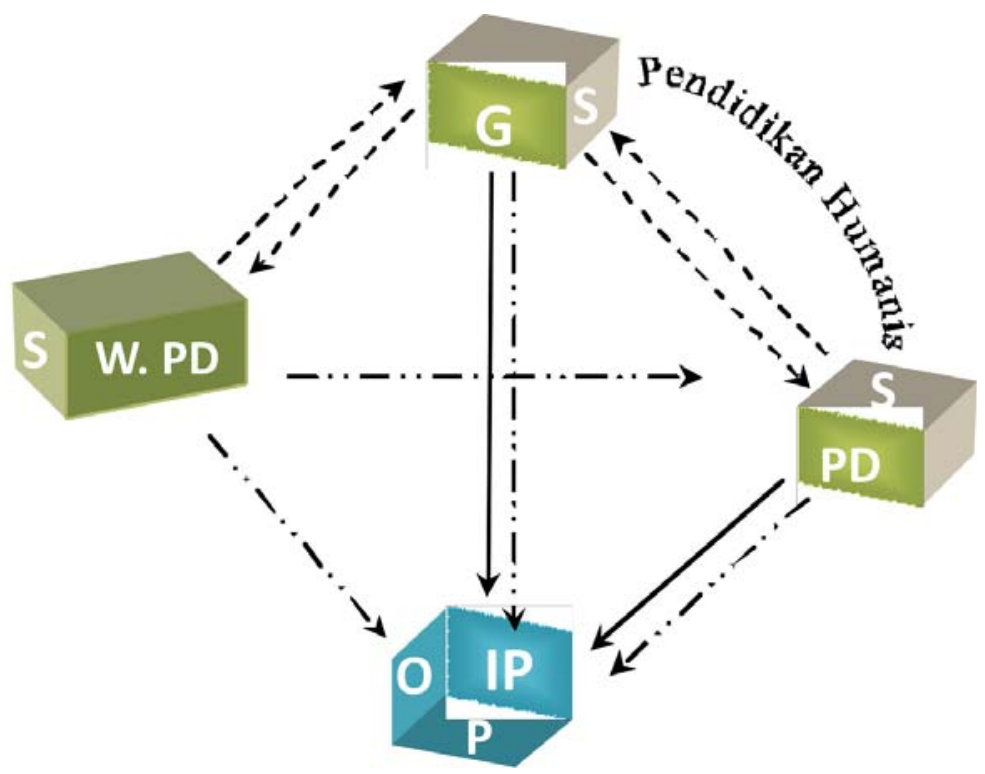

Gambar 2. Relasi Simbiosis - Trilogi +1 Pembelajar

Keterangan:

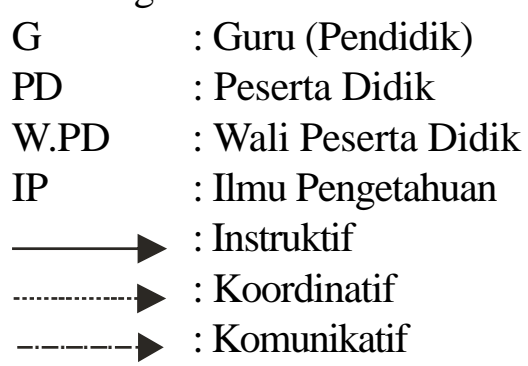

Oleh karena itu, memperbaharui konsep Freire dalam konteks pendidikan era kontemporer dengan berbagai tantangannya saat ini tentu membutuhkan/ melibatkan stakeholder inti lainnya, yang dalam hal ini adalah orangtua (wali) peserta didik. Sebagaimana kerangka konsep "relasi simbiosis trilogi+1 pembelajar" di atas, menggambarkan bahwa dalam proses penyelenggaraan pembelajar, guru (G) tidaklah berposisi pemeran tunggal, akan tetapi guru berfungsi sebagai mitra koordinatif peserta didik. Selanjutnya, 'peserta didik' (PD) dapat mengembangkan berbagai potensi dirinya dengan ideide kreatifnya, sehingga guru dapat 
mensupportnya, mengapresiasinya, serta memberikan penguatan-penguatan terhadap setiap capaian-capaian 'ilmu pengetahuahun' (IP) yang didapatkan oleh peserta didik.

Sedangkan 'wali peserta didik' (W.PD), berposisi sebagai mitra koordinatif-komunikatif dengan guru (G), sekaligus sebagai mitra apresiatif dengan 'peserta didik' (PD). Tugas wali peserta didik adalah berupaya untuk mensinergikan pembiasaan baik yang didesain dan diterapkan di sekolah, berkoordinasi menyelesaikan masalah-masalah penyimpangan perilaku peserta didik serta berbagai solusi yang dapat diputuskan bersama, sehingga terbentuk kebiasaan positif, peserta didik mantap di dalam menentukan sikap, berperilaku, 'berpikir' serta berbagai hal yang sevisi dengan program yang di kembangkan di sekola Itulah wujud apresiasi yang ditunjukkan oleh wali peserta didik di lingkungan keluarga, sehingga antara guru dengan wali peserta didik secara komunikatif senantiasa terjalin dengan baik.

Pada pola relasi simbiosis tiga arah ini ketiganya sama-sama berstatus sebagai pelaku (subjek) yang secara bersama mendukung proses pendewasaan peserta didik.

Secara tata bahasa di dalam struktur ketata-kebahasaan, bahwa apabila terdapat 'subjek', maka secara umum membutuhkan 'objek', akan tetapi dalam hal-hal tertentu 'subjek' tidak membutuhkan 'objek'. Dalam trilogi+1 pembelajar, yang disebut sebagai subjek adalah Guru (G), Peserta Didik (PD), dan Wali Peserta Didik (W.PD). Apabila hal ini mengacu pada teori Freire an sich maka ilmu pengetahuan (IP) berstatus sebagai objek, atau berstatus sebagai 'titik sasar' pengembangan, sehingga memunculkan asumsi, ilmu pengetahuanlah yang hanya dapat berkembang dengan baik, sementara 'sasaran pengembangan mental' dari peserta didik dimaksud tidak sampai pada titik capai kedewasaan yang diharapkan. Dengan demikian proses pembelajaran tetap tidak mampu melahirkan peserta didik sebagaimana yang dicita-citakan.

Oleh karena itu peneliti berpandangan bahwa IP tidak hanya dijadikan sebagai objek pengembangan, tetapi lebih utama dari hal tersebut adalah menjadikan ' $I P$ sebagai Media Aplikasi dan Pengembangan bagi' mental peserta didik. Dalam artian, peserta didik, baik di lingkungan sekolah dan juga di lingkungan keluarga tetap terkait dengan ilmu pengetahuan.

Perspektif ini tentu membawa kesan, bahwa peserta didik tidak memilki area dan waktu untuk bermain. Tentu pemahaman tersebut adalah kurang tepat, mengingat sinergitas guru, wali peserta didik dan peserta didik di sekolah dan juga di lingkungan keluarga untuk pengembangan mental anak melalui pembiasaan ilmu pengetahun, hendaknya masuk di semua ranah, termasuk pada waktu dan area khus bermain yang menjadi kegemaran setiap peserta didik, sehingga berbagai aktifitas yang dilakukan peserta didik selalu memberikan kesan 'kreatif' dan 'menyenangkan'.

Secara umum pola layanan 'trilogi+1 pembelajar' di atas merupakan konsep humanis yang didesain secara khusus dengan menghilangkan ego sentris dari ketiga subjek-subjek pembelajar. Dengan trilogi+1 pembelajar di atas diharapkan tidak ada lagi yang mengklaim, 'siapa' yang lebih berkuasa, lebih pintar, lebih bermoral, dengan melegalisir tindakantindakan 'kekerasan' dalam berbagai jenis dan bentuknya. Sebaliknya yang tampak 
adalah rasa humanitas dengan sepenuh kesadaran diri dari seorang guru untuk mengabdi sesuai dengan tugas pokok dan fungsinya, sesuai dengan kompetensi yang dimilikinya, bekerja sama dengan wali peserta didik dengan koordinasi dan komunikasi, serta memperlakukan peserta didik secara ramah, mengasihi dan menyayangi dengan baik.

\section{SIMPULAN}

Berdasarkan berdasarkan uraian analitis di atas dapat disimpulkan, bahwa: Perilaku humanitas pendidik terhadap peserta didik dalam proses pendidikan pada salah satu sekolah dasar di Blimbing dan salah satu sekolah dasar di kecamatan Buring kota Malang masih menemui kendala paradigmatis; Guru masih berpandangan 'kekerasan' yang dilakukan, baik disengaja/tidak disengaja dapat memicu lahirnya spirit dan kemauan belajar anak. Proses pembelajaran di kelas masih menggunakan pendekatan threats of violence. Pembelajaran masih terpusat pada guru. Guru belum dapat disebut sebagai pendidik yang humanis.

Maka sebagai tawaran konsep dalam penelitian ini, penting untuk ditingkatkan motivasi intrinsik-ekstrinsik dari kompetensi guru melalui re-awareness terhadap potensi yang harus dimiliki secara personal, serta melalui penguatan-penguatan apresiasi diri secara natural, sehingga seorang guru tampil sebagai mahluk sosial yang elegan, dedikatif dan menyenangkan. Selain dari itu, juga penting untuk ditingkatkannya motivasi ekstrinsik melalui penyehatan sistem manajerial keorganisasian, sehingga mampu memberikan apresiasi terhadap kinerja seorang guru. Dampaknya, kompetensi guru akan menguat, interaksi diri dan peserta didik akan lebih humanis.
Selain dari itu, juga penting untuk ditingkanya pola layanan trilogi+1 pembelajar. Konsep trilogi+1 pembelajar dimaksud, yakni konsep pembaruan dalam pendidikan, yang dikembangkan dari tri pusat pendidikan dan tri logi pendidikan Freire. Selanjutnya dikembangkan, dan melahirkan pola partisipatoris secara aktif (S) dan pasif $(\mathrm{P}, \mathrm{O})$ dengan melibatkan guru (S), wali peserta didik (S), peserta didik (S) dan ilmu pengetahuan (P, O). Disebut +1 pembelajar, karena juga melibatkan wali peserta didik yang juga sama-sama sebagai pembelajar, meskipun tidak dalam 1 lokasi pembelajaran. Ketiganya merupakan pelaku-pelaku pembelajar melalui garis koordinatif, komunikatif, dan apresiatif. Sedangkan yang menjadi sasaran $(\mathrm{O})$ dan medianya $(\mathrm{P})$ adalah ilmu pengetahun. Dari konsep trilogi+1 pembelajar, diharapkan terjadi jalinan koordinasi, komunikasi dan apresiasi secara humanis, sehingga tidak ada lagi pendidikan yang dehumanis.

\section{DAFTAR PUSTAKA}

Buku:

A.Smith, William. 2001. Conscientizacao, tujuan pendidikan Freire. Yogyakarta: Pustaka Pelajar bekerjasama dengan REaD Book (Research, Education and Dialogue) Assegaf, Abd. Rahman. 2004. Pendidikan tanpa kekerasan, tipologi kondisi, kasus dan konsep. Yogyakarta: Tiara Wacana Yogya

Freire, Paulo. 2005. Pengantar ReaD, Politik Pendidikan; Kebudayaan, Kekuasaan dan Pembebasan, pada sub pokok bahasan Model Pendidikan yang Membelenggu dan Membebaskan 
Freire, Paulo. 1995. Pendidikan Kaum Tertindas, terjemahan Utomo Dananjaya, (Jakarta - LP3ES (Lembaga Penelitian Pendidikan dan Penerangan Ekonomi dan Sosial)

Miles dan Huberman. 1987. Analisis Data Kualitatif. Terjemahan. Jakarta: Yayasan Penerbitan Universitas Indonesia

Mu'in, Fathul. 2011. Pendidikan karakter; konstruksi teoritik dan praktif. Jogjakarta: Ar-Ruzz Media

Moleong, Lexy J. 2006. Metodologi Penelitian Kualitatif. Bandung: Remaja Rosda Karya

Murtiningsih, Siti. 2004. Pendidikan Sebagai Alat Perlawanan, Teori Pendidikan Radikal Freire. Yogyakarta: Resist Book

Muri'ah, Siti. 2011. Pembebasan pendidikan dalam perspektif barat dan timur. Jogjakarta: Ar-Ruzz Media

Nasional.kompas.com/read/ 2014 /05/ 07/ 0527140/ Indonesia_ darurat_ kekerasan_ pada_ anak. edisi, Minggu, 8 Pebruari 2015

Nasution. (2006). Metode Research (Penelitian Ilmiah). Jakarta: Bumi Aksara.

R.C, Bogdan., dan Biklen, S.K. 1998. Qualitative Research for Education. Boston: Allyn and Bacon

Suharsimi, Arikunto. 2002. Metodologi Penelitian. Penerbit PT. Rineka Cipta. Jakarta

Peraturan Pemerintah Nomor 19 tahun 2005 tentang Standar Nasional Pendidikan

Shor, Ira., dan Freire, Paulo. 2001. Menjadi Guru Merdeka; Petikan Pengalaman, terjemahan Nasir Budiman. Yogyakarta: LKiS bekerjasama dengan Yayasan Adikarya IKAPI \& the Ford Foundation
Undang-Undang Nomor 14 tahun 2005 tentang Guru dan Dosen

Zainul, Fitri.Agus. 2012. Reinventing human character; pendidikan karakter berbasis nilai dan etika di sekola Jogjakarta: Ar Ruzz Media.

\section{Artikel dalam Jurnal:}

Zaini, Mo 2014. Esensi spirit pendidikan Islam dalam konsep pemikiran Freire. El-Qudwah; Jurnal penelitian integrasi sain dan Islam. Vol. 9. No. 2, 79-93. 